\title{
Higher Education Reform in Bangladesh: An Analysis
}

\author{
Dr. Md. Moazzom Hossain \\ Deputy Registrar, Feni University, \\ Email:moazzom@hotmail.com/registrar@feniunivesity.edu.bd
}

Amir Mohammad Khan

Lecturer of English, Feni University Email: amir_khan.chu@yahoo.com

\section{Doi:10.5901/mjss.2014.v5n9p423}

\section{Abstract}

This article focuses on the gradual development and reform of Higher Education (HE) system throughout the last 40 years or so in Bangladesh. To properly show the scenario of the educational development a discussion on various education commissions is done and some recommendations are given to conclude. The Qudrat-E-Khoda Commission (1974) basically highlights the colonial deprivation of two hundred years and some other problems in the HE system like traditional memorizing system and lack of research and empirical studies. Secondly, Jatiya Shikhah Upadeshta Parishad (1979) finds out some problems like HE having no relation with the country and the state and lack of sufficient facilities in the newly established colleges. The other commissions focus on quota problem, the teachers' fascination to private coaching, lack of professional knowledge of teachers etc. Besides, the recommendations of these commissions are: HE should be related to the demand of the nation, expansion of practical education, introduction of new academic disciplines, introduction of four years' Bachelor of Honours and one year Masters, involvement of private sector in HE, more funds and facilities for research, the syllabus and curriculums to be modern and international standard etc. Our HE system actually came from the British and from time to time it is used politically. Not only in the colonial days but also after independence HE system was influenced by the ruling party. Finally, HE should function properly for sustainable development in the country and so reform is inevitable.

Keywords: Higher Education, Reform, Bangladesh, Analysis, Commissions.

\section{Introduction}

Bangladesh is a new state with a long history. It has been described "as a country challenged by contradictions." The country is a natural bridge between South and South East Asia. Because of its location, it is treated as intermediary in trade and commerce between the South Asian Sub-Continents and the Far East. ${ }^{1}$ So, Education is an integral part for its development and existence in the arena of the international community. Due to the scarcity of resources it is extremely difficult to trace out the starting point of Higher Education(HE) system in Bangladesh. Available sources allow us to reconstruct a generalized idea about the HE reform system in ancient and medieval periods. However, in the colonial period the picture became clear to enable us to trace the development of Education in a much more logical way. ${ }^{2}$ Higher Education system in Bangladesh has a long way of more than one hundred and fifty years of intellectual development. During the British rule only a privileged group got access to education and gradually isolated themselves from the general masses of the country. Universal primary education is a priority policy of Educational reform in Bangladesh government since independence. So, article No 17 of the constitution stated free and compulsory education that, "The state shall adopt effective measures for the purpose of- (a) Establishing a uniform, mass-oriented and universal system of education and existing free and compulsory education to all children to such stage as may be determined by law; (b) Relating education to needs of society and producing properly trained and motivated citizens to serve those needs; and (c) Removing illiteracy within such time as may be determined by law."3Here in the followings the development of Bangladesh HE reform is presented briefly through various commissions:

\section{The Bangladesh Education Commission Report (1974)}

The Bangladesh Education Commission was formed by the leadership of Qudrat-E-Khuda, it traced out some limitations 
of HE i.e. (a) HE had no relation with practical problems and full of colonial deprivation of two hundred years;

${ }^{*}$ The $1^{\text {st }}$ writer is the Deputy Registrar of Feni University and the $2^{\text {nd }}$ writer is the Lecturer of English, Feni University.

(b) Traditional HE system which was fully dependant on memorizing system and bore a defective examination system; (c) A few numbers of meritorious students enrolled in HE and maximum of them were below the marks in quality; and (d) The defective extension of college affiliating system which had no relations with the research and empirical studies. ${ }^{4}$ The commission gave special recommendation for the development of HE on the following grounds: ${ }^{5}$ (i) HE should be closely related with aspirations and economic activities of the nations ; (ii) Library is the most effective unit for the development of HE. So, Introducing Library Science as diploma and Honours education in the degree colleges and universities;(iii) Updating the syllabus and curriculums of the traditional subjects relating to science and arts faculties; (iv) HE must be opened for all classes of the society and the selection in this level would be restricted for meritorious students; (v) The degree colleges should start Honours Programmes with special priority; (vi) After completing Masters programme the tenure of PhD would be for three years for the advanced students; (vii) Science and technical education should be expanded and university must be developed self-sufficiently; (viii) Tutorial and internal examination system must be introduced in the HE as a substitute of annual and external examination system; (ix) Research should be added in every branches of HE i.e. Bachelors, Masters and PhD level. And in every colleges and universities there must be a laboratory for the extension of experimental knowledge; $(x)$ Affiliating university must be established in all divisions for lessening the over burden of Dhaka, Rajshahi and Chittagong Universities. The affiliating university would be a full fledged university consisting of Vice Chancellor, Registrar, Syndicate, Senate, Academic Council, Selection Committees and Examination Committees; and (xi) Included the concept of university colleges in the HE system of Bangladesh and these colleges would be developed like the universities.

\section{Jatiya Shikkah Upadeshta Parishad(1979)}

The commission was formed in 1979 by the leadership of MA Baten later named as Ontorbartikalin Shikhaniti. It had given special priority on HE system and traced out various drawbacks i.e. ${ }^{6}(a) \mathrm{HE}$ had no relation with society and state, (b) Establishment of new colleges without sufficient facilities and (c) Teachers had no relation in the research work without a few. Moreover, it had delivered some recommendations for the development of HE as given in the followings ${ }^{7}$ : (i) HE related colleges would be determined by the district education authority as per population, geographical condition and the salary structure of non-government colleges would be similar to the government colleges; (ii) Upgrading the education from the lower levels and creating proper environment in the HE institutes by providing sufficient equipments, removing teacher-student conflicts and other problems; (iii) New academic discipline would be initiated in the HE institutes regarding the geographical and natural position i.e. Hydrology, Oceanography, Anthropology, Disaster Management and others; (iv) Update the courses and curriculums of HE relating to the changing situation; (v) Unified education facility in the colleges and universities for the same standard students and introducing academic calendar for classes; (vi) Bengali would be the medium of instruction for the HE and English would be compulsory in Bachelor of Honours and Pass courses for the proper development of students; (vii) Part time HE system would be provided for the professional classes of the society; (viii) Arrange well equipped libraries for all educational institutes with laboratories and other necessary equipments; and (ix) Empirical studies should be arranged in agriculture and industry as the unit of economic development.

\section{Jatiya Shikkah Nity Pranayan Committee(1997)}

Jatiya Shikah Nity Pranayan Committee was headed by Prof Shamsul Hoq in 1997 and it is called as Shamsul Hoq Commission. The commission had given the following recommendations; 8 (a) Fixing qualification on merit and avoiding of quota; (b) For maintaining standard of $\mathrm{HE}$, priority would be given to select the teachers on the basis of merit and research in promotion; (c) Introducing unified four years' Bachelor of Honours and one year Masters courses in the universities and three years' bachelor degree courses in the colleges but the advanced colleges can continue for four years' Bachelor of Honours courses and one year Masters courses. The tenure of Masters courses for Bachelor degree holders would be two years and these courses and curriculum would be controlled by National University; (d) Initiating research facilities in the bachelor degree colleges as well as the universities; (e) The courses and curriculums of HE should be modern and global oriented where English would be the second language after Bengali; (f) Admission fee and salary of the students should be standard for ensuring quality education and it may be managed from the government grants, tution fees, bank loan and personal credits; (g) NU would be treated as the central university of the country in the 
context of its various assignment to the nation; and (h) Special emphasis would be given to the establishment of library and research institutions in each university/institute.

\section{MA Bari Commission-2002}

The commission was formed by the chairmanship of Prof. Dr MA Bari, Known as Bari Commission. The commission had some special observation to the HE system of Bangladesh. It formed various sub-committees and the most important one was college education sub committee. The then VC of the NU was the chairman of this sub committee and it traced out the following Problems of college oriented HE in Bangladesh as given below ${ }^{9}$ :

(a) Problems in Class Presentation: There is shortage of teachers in most of the colleges; maximum teachers have the fascination to private or coaching classes for additional earnings. The college authority lessened the class tenure from 50 to 40 minutes; (b) Irregularities in the Examinations:The college examinations are hampered by the direct involvement of college teachers in various job tests in maximum weeks of the year. Various procession of students delaying of examination schedule, and irregularities in various colleges assessment tests like tutorial/in course examinations; (c) Lack of Academic Calendar: Maximum colleges are unconscious about academic discipline and calendar of the NU, they usually show negligence to obey the academic rules of the NU; (d) Shortage of Teachers and Students Ratio: There are shortage of students in every HE levels i.e. Degree, Honours and Masters level and the low ratio of teachers and students are prevailing in maximum affiliated colleges, where standard ratio is 1:15 but in the NU affiliating colleges it is 1:30; (e) Weak Administrative Structure in Colleges: Weaker administrative and financial structure in the colleges hampered accountability; ( $f$ ) Lack of Professional Knowledge of Teachers: There is limited scope for developing the professional knowledge of the college teachers; (g) Problems in Inspection: In the Inspection system, though some bindings are prevailed i.e. qualification of teachers of colleges, books in libraries, equipments in laboratory, financial solvency and other criteria but these are not maintained properly;(h) Multi Dimensional Problems in NU and Colleges: Multi dimensional problems prevailed in the NU and affiliating colleges on the issue of governing body, inspection, course and curriculum, question moderation and result publications; (i) Irregularities in Teachers' Recruitment of Non Government Colleges: The donation and political linkage system also hampered the selection process of non government colleges' teachers; (j) Political Influence in the Campus: The political influence in the college campuses hampered the class system, tender process, admission procedure and all other academic activities; and $(k)$ Unfair Means in Examination and Violence in the Campus: In the examination system the practice of unfair means and the political violence also hampered the normal academic activities of the colleges.

\section{Mohammad Moniruzzaman Mia Commission-2003}

This commission was formed by the guidance of educationist Professor Mohammad Moniruzzaman Mia on January 2003. The commission submitted its report to the government on March 2004. In order to Improve the quality of HE it recommended the following issues: ${ }^{10}(\mathrm{a})$ Increasing access to HE in the rural areas through establishment of new colleges/institutes with government financing in the underserved areas; (b) A national policy for utilization of manpower needs to be formulated sothat no educated unemployment is generated; (c) Introducing a uniform examination and evaluation system through grading at all stages of education, and special emphasis on HE for measuring students' attainment whether the poor performing students are progressing to attain a certain level of competence; (d) Establishment of Unit rack universities like Agriculture, Technology and Medicine. Government fund should be discouraged as these are contradictory to the concept of university in one hand and expensive as well on the other; (e) $\mathrm{HE}$ in private sector could be encouraged, but institutional mechanisms should be established to maintain quality of private sector education; (f) Establishing impartial administration following the 1973 University Autonomy Act; (g) For facilitating the public university research with international standard, center of excellence would be established in some areas of education; (h) For expanding effective HE system, a national policy on language needs to be formulated; (i) in the global age of $21^{\text {st }}$ century, with the light of the knowledge of modern science and technology, a national policy on science should be formulated and implemented at the earliest possible time; and (j) Establishment of a permanent education commission in the country, which assigned to be identifying of the problems in education sector and recommendation for solutions through continuous research.

\section{Kabir Chowdhury Commission 2009}

After the election of December 29, 2008, Awami League leaded great alliance government came in power with three 
fourths majorities. For proper development of education a committee was formed by the chairmanship of Professor Kabir Chowdhury and co-chaired by eminent economist Dr Khaliquazzaman Ahamed on May 2009. The committee submitted its report to the government on November 2009. After various analyses with different groups of intellectuals, it finalized the drafts on education policy. And on December 08, 2010 it was passed in the Nine Jatiya Sangsad as education policy 2010. The main criteria of this policy regarding the techniques of $\mathrm{HE}$ are given below:

(a)After completing the various levels of pre-HE successfully, the candidates would get the chance for HE according to merit, fascination and aptitude; (b) Special residence facility, and stipend facility would be provided for the children of freedom fighters and tribal/aborigine people; (c) For maintaining quality only dignified colleges and universities would be fixed for providing HE and the minimum qualification would never be relaxed for quota; (d) Providing various actions for developing the quality of HE; (e) Four years' Bachelor of Honours degree would be treated as the finishing point of $\mathrm{HE}$ and the qualification for getting job, but in teaching profession post graduation is the minimum qualification. Gradually the three years' degree colleges would be turned into four years' honours colleges; (f) Masters, M.Phil/PhD degree would be treated as professional degree; Postgraduate degree would be provided only for the interested candidates of teaching professions. For extending research activities each department of every university should start Masters, M.Phil/PhD programmes; (g) In the degree courses of every colleges and universities three credits of 100 marks English would be compulsory for each student; (h) In the research activities students and teachers would participate actively. Priority would be given to the meritorious students of every university and arrangement of fellowship like Bangabandhu and other great men would also be introduced. The degree colleges would also provide enough facilities for expanding research programmes; (i) The syllabus and course curriculums of HE would be modern and equivalent to international level. Extension of Bengali in $\mathrm{HE}$ level and the valuable books written in English version in every discipline must be translated into Bengali version. But in HE level, English language would continue apart from Bengali; (j) Developing HE with the international level, sufficient investment would be provided. For this, government donation, salary of the students and more grants from the private sector would also be encouraged; ( $k$ ) Special stipend would be provided for the meritorious students based on the financial condition of the guardians. Moreover, soft loan system would be arranged for the meritorious and poor students. (I) Technical Institute or Special University would be established, for developing jute, textile and leather sectors; $(\mathrm{m})$ Libraries of each university and colleges would be well equipped and connected with network technology for the readers of the twenty first century. Gradually update the books and journal of each library, as a digital edition; (n) Providing sufficient trainings for the teachers, and ensure the co-existence of teachers of colleges and universities. Moreover, the universities would arrange various subject wise trainings during vacations; (0) Each university and college would be guided by the academic calendar, where there would be schedule for starting classes and examinations. This calendar would be followed strictly and (p) The HE system of private universities especially on courses and curriculums, level of educations, qualifications of teachers would be same as of the public universities. These private universities would be also open for all classes of the society. It would not be used in any commercial purposes and may not be contradictory to the spirit of Liberation War, national culture and heritage.

\section{Conclusion}

Educational reform in Bangladesh has a history of more than forty two years' development process that evolved in the colonial days and bore the mark of its alien origins for a century or more. In this long path the various cultural elements of internal and external factors influenced this development process. Basically the HE system in this area was not so much result oriented; it started only to help British Administration. But after the departure of the colonial authority, various commissions were formed and many recommendations were made for the development.These recommendations became mere directions and were not implemented properly just for the political aggression of governments. Hence, Bangladesh has no specific Education Policy at all. However, each and every government formed Education Commissions and the next governments never implemented these policies due to political conflicts or misunderstandings. But for the sustainable development of Bangladesh there is no alternative to implement the HE policy properly and by virtue of these factors Bangladesh can easily acquire the targets of MDG and the vision of $21^{\text {st }}$ century.For the proper development of Bangladesh every government should be conscious and never treat the organs of $\mathrm{HE}$ as political weapons. Otherwise our position would be hampered in the global context. Finally, the proper implementation of $\mathrm{HE}$ policy and reform is needed for our sufficient and sustainable development. 


\section{References}

Bangladesh Ministry of Information, Government of the People's Republic of Bangladesh,"Bangladesh Towards 21st Century", 2000, p-1 Ehsan Mohammad, "Higher Education Governance in Bangladesh-The Public Private Dilemma", AH Development Publishing House, Dhaka, 2008, pp-47-48

The Constitution of the People's Republic of Bangladesh, Legislative and Parliamentary Affairs Division, Ministry of Law, Justice and Parliamentary Affairs, October 2011, Article no- 17, pp-11-12

Bangladesh Shikkha Commission Report, Ministry of Education, Government of Bangladesh, May 1974, pp8-85, Ibid, pp-85-95

Ontorbortikalin Shikhaniti, Ministry of Education, Government of Bangladesh,1979,Dhaka,p-25, Ibid, pp-26-32

Jatiya Shikha Nity Pranayan Committee 1997, Ministry of Education, Government of Bangladesh, pp86-90

Shikha Shaskar Bishashgo Committee-2002, Ministry of Education, Government of Bangladesh,pp-43-53

Mohammad Moniruzzaman Mia Commission-2003, Ministry of Education, Government of Bangladesh, pp-179-187

Education policy 2010, Ministry of Education, Government of Bangladesh,pp-22-24 